\title{
Ya-hom, a Thai herbal remedy, has opposing effects on histaminergic and cholinergically mediated acid secretory related responses in gastric glands isolated from rabbits
}

\author{
Wisuda Suvitayavat ${ }^{1}{ }^{*}$, Hai-Yen Qin ${ }^{2}$, Suwan Thirawarapan ${ }^{1}$, Nuntavan Bunyapraphatsara ${ }^{3}$, Catherine S Chew ${ }^{2}$ \\ 1 Department of Physiology, Faculty of Pharmacy, Mahidol University, Bangkok, Thailand \\ 2 Augusta University, Augusta, GA 30912, USA \\ 3 Department of Pharmacognosy, Faculty of Pharmacy, Mahidol University, Bangkok, Thailand
}

\begin{abstract}
Ya-hom, a Thai traditional medicine, is used as a treatment for gastric discomfort. We previously found that Ya-hom inhibits both histamine and carbachol-stimulated acid secretion in gastric fistula rats. Herein, we used isolated gastric glands and highly enriched parietal cells from rabbit to determine whether or not Ya-hom acts directly on the acid-secreting parietal cell. Ya-hom inhibited carbachol-stimulated $\left[{ }^{14} \mathrm{C}\right]$ aminopyrine (AP) accumulation in rabbit gastric glands and prevented carbachol-induced elevation of $\left[\mathrm{Ca}^{2+}\right]_{\mathrm{i}}$ in parietal cells. In contrast, Ya-hom potentiated histamine-stimulated AP accumulation and increased the stimulatory effect of the specific adenylyl cyclase activator, forskolin, in the presence of the histamine $\mathrm{H}_{2}$ receptor antagonist, cimetidine. Ya-hom had no effect on downstream cAMP-dependent signaling events including phosphorylation of LASP1 (LIM and SH3 domain protein 1), and F-actin redistribution. Because the cholinergic signaling pathway is mediated via calcium-dependent mechanisms, we compared effects of Ya-hom on carbachol-induced elevation of $\left[\mathrm{Ca}^{2+}\right]_{i}$ with those of thapsigargin, a specific endoplasmic reticulum $\mathrm{Ca}^{2+}$ pump inhibitor that also potentiates histamine-stimulated AP accumulation. Both agents similarly potentiated histamine-stimulated AP accumulation and their actions were not additive. Furthermore, Ya-hom inhibited thapsigargin-induced elevation of $\left[\mathrm{Ca}^{2+}\right]_{\mathrm{i}}$. Based on these findings, we postulate that Ya-hom induces a slow release of calcium from intracellular stores thereby suppressing the cholinergic response and potentiating the cAMP signaling pathway linked to the histamine response. Since Ya-hom directly inhibits the stimulatory effect of carbachol on acid secretion, the gastric action of this herbal remedy may target vagally-dependent $\mathrm{HCl}$ secretion.
\end{abstract}

\section{Keywords:}

Ya-hom, Gastric acid secretion, Gastric glands, Parietal cells, Intracellular calcium, Histamine, Carbachol

\section{INTRODUCTION}

Ya-hom is a folk formula that is used to treat fainting, nausea, vomiting and gastric discomfort. This traditional remedy comprises of various types of herb as in Table 1. Most scientific reports have focused on effects of specific Ya-hom components on the cardiovascular system. To date, only a few reports have addressed effects of certain of these components on the gastrointestinal system where G. glabra ${ }^{1}$ and $M$. arvensis $^{2}$ has been shown to inhibit gastric acid secretion, G. glabra $^{3}, A$. lappa $^{4}$, and C. cassia ${ }^{5}$ to have antiulcer activity, and $G$. glabra $^{6}$, M. officinalis ${ }^{7}$, A. lappa ${ }^{8}$, S. aromaticum $^{9,10}$ and A. gramineus $^{11}$ to have spasmolytic activity. Currently, there is lack of knowledge concerning the overall effect of Ya-hom on gastrointestinal function. Since stomach discomfort can be caused by increased gastric acid secretion, we previously analyzed the effect of Ya-hom on gastric secretion to verify its benefit as a potential acid secretory suppressant and, hence, a beneficial

*Corresponding author:

*Wisuda Suvitayavat Wisuda.suv@mahidol.ac.th 
Table 1. The composition of Ya-hom.

\begin{tabular}{llc}
\hline \multicolumn{1}{c}{ Scientific name } & Family & g in 100 g of Ya-hom \\
\hline Agastache rugosa (Fisch. \& C.A.Mey.) Kuntze & Lamiaceae & 7.1 \\
\hline Acorus gramineus Aiton & Acoraceae & 3.5 \\
\hline Lysimachia foenum-graecum Hance & Primulaceae & 3.3 \\
\hline Citrus nobilis Lour. & Rutaceae & 7.1 \\
\hline Magnolia officinalis Rehder \& E.H.Wilson & Magnoliaceae & 11.8 \\
\hline Cinnamomum cassia (L.) J.Presl & Lauraceae & 7.1 \\
\hline Mentha arvensis L. & Lamiaceae & 3.5 \\
\hline Asarum sieboldii Miq. & Aristolochiaceae & 2.3 \\
\hline Ligusticum striatum DC. & Apiaceae & 9.3 \\
\hline Glycyrrhiza glabra L. & Fabaceae & 4.8 \\
\hline Syzygium aromaticum (L.) Merr. \& L.M.Perry & Myrtaceae & 7.1 \\
\hline Aucklandia lappa DC. & Asteraceae & 7.1 \\
\hline Aquilaria malaccensis Lam. & Thymelaeaceae & 7.1 \\
\hline Atractylodes ovata (Thunb.) DC. & Asteraceae & 9.3 \\
\hline Angelica anomala Avé-Lall. & Apiaceae & 3.5 \\
\hline Menthol & - & 4.7 \\
\hline Borneo camphor & - & 1.4 \\
\hline
\end{tabular}

treatment for gastric discomfort. Using a rat gastric fistula model, we have demonstrated that the water extract of Ya-hom inhibits both carbachol and histamine-stimulated gastric acid, pepsin and soluble mucus secretion but increases visible mucus secretion ${ }^{12}$. The water extract of Ya-hom also inhibits histamine and cholinergic agonist-stimulated gastric acid secretion in stomachs isolated from mice ${ }^{13}$.

In the present study, we examined the effects of the water-soluble extract of Ya-hom on cellular acid secretory responses and subcellular signaling pathways. The in vitro investigations were performed using rabbitderived tissues, including isolated gastric glands, acutely isolated highly enriched parietal cells and primary culture of parietal cells.

We selected the rabbit model for several reasons. Firstly, the rabbit (Oryctolagus cuniculus) has proven to be an enormously useful model for the analysis of cellular and subcellular mechanisms of gastric acid secretion. Furthermore, this species has a close phylogenic proximity to humans and, now that the genome has been sequenced, is expected to become an important translational mode, facilitating efforts to bridge the gap between small rodent models and larger primates ${ }^{14}$. Most notably, with regard to the present study, rabbits display in vivo acid secretory responses that are similar to humans ${ }^{15}$.

To assess cellular acid secretory responses, we used a well-characterized gastric gland model $^{16-20}$, a semi-intact gastric mucosal isolate composed of acidsecreting parietal cells, pepsinogen secreting chief cells, mucous neck cells along with a few histamine-containing enterochromaffin-like (ECL) cells ${ }^{16}$. In glands, cell-cell contacts and polarities are maintained and parietal cell secretions accumulate within a sealed off luminal space. Neural and hormonal influences are absent. Parietal cell acid secretion is assessed indirectly by measuring accumulation of ${ }^{14} \mathrm{C}$-aminopyrine (AP) within the gland lumens. AP is a weak base with a pKa of 5. It traverses cellular membranes freely when unprotonated but becomes cell impermeant upon protonation. Thus, AP is specifically trapped when it enters highly acidic compartments uniquely associated with $\mathrm{HCl}$ secreting parietal cells ${ }^{16}$. Traditionally, AP accumulation in gastric glands is expressed as the ratio of ${ }^{14} \mathrm{C}$-labelled AP trapped within acidic intra-versus extra-glandular compartments. Thiocyanate ( $\mathrm{SCN})$, which has been shown to completely block specific AP accumulation, is used to correct for non-specific trapping of AP in pelleted glands ${ }^{17}$ and was similarly used in the present study. Because glands contain histamine-secreting ECL cells, agonists such as acetylcholine and analogs such as carbachol and bethanechol have the capacity to elicit the release histamine from these cells thereby confounding direct effects of these agents. To avoid such influences, histamine $\mathrm{H}_{2}$ receptor antagonists such as cimetidine, ranitidine, etc. can be added to glandular preparations prior to cholinergic stimulation.

Following the successful isolation and characterization of gastric glands, additional models were developed to expand the understanding of acid secretory mechanisms to the level of the parietal cell itself. These models included acutely isolated, highly enriched parietal cells and primary cultures of parietal cell isolates. Both models have been shown to respond appropriately to secretagogue stimulation and have proved to be a proper model for analysis of specific parietal cell signaling events ${ }^{21-26}$ as shown in the present 
study. In the present study, these models were similarly employed.

\section{MATERIALS AND METHODS}

\subsection{Materials and animals}

Ya-hom was obtained from Five Pagodas Pharmacy Co. Ltd., Thailand. The water-soluble form was prepared by boiling Ya-hom in water for $15 \mathrm{~min}$ at a ratio of $1 \mathrm{~kg}: 10 \mathrm{~L}$. After filtration through cotton and muslin cloth, the clarified substrate was lyophilized and stored at $-20^{\circ} \mathrm{C}$. Ya-hom extract was analyzed for total sugar content, uronic acid and phenolics. Total neutral sugar content was determined by the reaction with phenol in the presence of sulfuric acid using glucose as a standard. The total uronic acid content was colorimetrically determined by the m-hydroxydiphenyl assay using galacturonic acid as a standard. Total phenolics were determined using Folin and Ciocalteu Reagent and calculated as gallic acid equivalents. Analyses revealed that the water-soluble extract contained phenolic acid (equivalent to gallic acid, $10.57 \mathrm{mg} / \mathrm{g}$ dry extract), polysaccharide $(5.9 \% \mathrm{w} / \mathrm{w})$ and uronic acid $(0.55 \% \mathrm{w} / \mathrm{w})$.

Dimethylamine- $\left[{ }^{14} \mathrm{C}\right]$-aminopyrine was purchased from NEN/Dupont, Wilmington, DE. Liquid scintillation, Scintisafe ${ }^{\mathrm{TM}} 30 \%$ was purchased from Fisher Scientific, Pittsburgh, PA. ECL detection was from Amersham Pharmacia Biotech UK Limited, Buckinghamshire, England, Oregon Green phalloidin was from Molecular Probes. Fura-2, thapsigargin and ionomycin were purchased from Calbiochem, La Jolla, CA. Optiprep was from GibcoBRL, Grand Island, NY. Matrigel was from Collaborative Biomedical Products, Bedford, MA. All other chemicals were obtained from Sigma Chemical, St. Louis, MO. Male New Zealand White rabbits with $4-5 \mathrm{~kg}$ of body weight were used for all experiments. All animal procedures were reviewed and approved by the Animal Care and Use Committee at the Medical College of Georgia, protocol no. 05-08167.

\subsection{Isolation of rabbit gastric glands}

Gastric glands were used to assess acid secretory responses using $\left[{ }^{14} \mathrm{C}\right]$-aminopyrine accumulation measurements and to assess effects of Ya-hom on cAMP-dependent morphological changes using a fluorescently-labelled (Oregon Green) phalloidin, a bicyclic peptide that specifically binds to F- but not G-actin. Glands were also used, along with isolated parietal cells, to analyze effects of Ya-Hom on LASP1 phosphorylation as explained below.

Isolated gastric glands were prepared and as previously described ${ }^{18-20}$. In brief, stomach of deeply anesthetized rabbits were perfused with phosphate- buffered saline (PBS; in mM: $149.6 \mathrm{NaCl}, 3 \mathrm{~K}_{2} \mathrm{HPO}_{4}$ and $0.64 \mathrm{NaH}_{2} \mathrm{PO}_{4}, \mathrm{pH} 7.4$ ), prewarmed to $37^{\circ} \mathrm{C}$ and gassed with $100 \%$ oxygen. The mucosa was stripped from gastric corpus muscle layers, finely minced and incubated with medium A (in mM: $114.4 \mathrm{NaCl}, 5.4 \mathrm{KCl}$, $5 \mathrm{Na}_{2} \mathrm{HPO}_{4}, 1 \mathrm{NaH}_{2} \mathrm{PO}_{4}, 1.2 \mathrm{MgSO}_{4}, 15$ HEPES, $1 \mathrm{CaCl}_{2}$, and $10 \mathrm{mg} / \mathrm{L}$ phenol red, $\mathrm{pH}$ 7.4) containing $1 \mathrm{mg} / \mathrm{ml}$ collagenase (type I) at $37^{\circ} \mathrm{C}$ for $25-30 \mathrm{~min}$. The resulting digest was filtered through a nylon mesh, rinsed three times with medium B (medium A plus $2 \mathrm{mg} / \mathrm{ml}$ glucose, $2 \mathrm{mg} / \mathrm{ml}$ bovine serum albumin (fraction $\mathrm{V}$ ), $0.11 \mathrm{mg} / \mathrm{ml}$ sodium pyruvate and $1 \mathrm{mM}$ DTT) and resuspended $1 \mathrm{ml}$ of 10 min gravity settling gastric gland in medium B to a final volume of $30 \mathrm{ml}$. Dry weights of the gastric gland suspensions were calculated as previously described ${ }^{18-20}$.

\subsection{Measurement of $\left[{ }^{14} \mathrm{C}\right]$-aminopyrine (AP) accu- mulation in gastric glands}

One $\mathrm{ml}$ aliquots of suspended gastric glands containing $0.1 \mu \mathrm{Ci}$ dimethylamine- $\left[{ }^{14} \mathrm{C}\right]$-aminopyrine (specific activity $100-115 \mathrm{mCi} / \mathrm{mmol}$ ) were diluted with $1 \mathrm{ml}$ medium $\mathrm{B}$ and gently agitated at $37^{\circ} \mathrm{C}$ for $30 \mathrm{~min}$ before adding carbachol or histamine or forskolin. Carbachol and histamine were dissolved in medium A. Forskolin, a specific adenylyl cyclase activator, thapsigargin, an intracellular $\mathrm{Ca}^{2+}$-ATPase inhibitor, and ionomycin, a nonspecific calcium ionophore were dissolved in DMSO (final concentration, $0.1 \%$ ) and a similar amount of DMSO vehicle was added to control flasks). Cimetidine $\left(\mathrm{H}_{2}\right.$ receptor antagonist, $\left.10 \mu \mathrm{M}\right)$ or Ya-hom were added at the beginning of incubation unless otherwise indicated. Glands isolated from a single rabbit were used for each separate experiment and all assays were performed in duplicate. At indicated times following addition of experimental agents, 1-ml aliquots of gland suspensions were withdrawn and immediately centrifuged $(10,000 \mathrm{rpm}, 10 \mathrm{sec})$. Supernatants were rapidly withdrawn, pellets were rinsed once with medium that did not contain $\left[{ }^{14} \mathrm{C}\right]$-aminopyrine then dissolved in $200 \mu \mathrm{l}$ of conc. $\mathrm{HNO}_{3}\left(50^{\circ} \mathrm{C}, 10 \mathrm{~min}\right)$. Aliquots of supernatants and acid extracts were counted in a liquid scintillation spectrometer. Results were expressed as the ratio of intraglandular (acid space) to extra glandular $\left[{ }^{14} \mathrm{C}\right]$-aminopyrine concentration and calculated with corrections for $\left[{ }^{14} \mathrm{C}\right]$-aminopyrine trapped in the pellet as previously described ${ }^{20,27}$.

\subsection{F-actin localization in gastric glands with fluorescently tagged phalloidin}

Isolated gastric glands were incubated in medium B with and without Ya-hom $\left(10 \mathrm{mg} / \mathrm{ml}, 37^{\circ} \mathrm{C}, 30 \mathrm{~min}\right)$ then stimulated with forskolin $(3 \mu \mathrm{M})$ for $15 \mathrm{~min}$. At the conclusion of incubation, gastric glands were rinsed once with PBS, resuspended in paraformaldehyde solu- 
tion (7\% paraformaldehyde, $0.25 \mathrm{M}$ sucrose and $0.05 \mathrm{M}$ cacodylate buffer, $\mathrm{pH}$ 7.0) and settled at room temperature for $15 \mathrm{~min}$. The fixed gastric glands were rinsed three times with PBS and stored in PBS containing $0.05 \%$ sodium azide at $4^{\circ} \mathrm{C}$. For fluorescent staining, glands were washed with PBS, permeabilized with $0.2 \%$ Triton X-100 in PBS for 15 min then fixed on slides. F-actin labeled with Orange Green Phalloidin (1:400 dilution) was analyzed by confocal microscopy as previously described ${ }^{28}$.

\subsection{Isolation and purification of rabbit parietal cells}

Parietal cells, enriched to $80-90 \%$ purity, were used to assess changes in $\left[\mathrm{Ca}^{2+}\right] \mathrm{i}$ at the single cell level and to define specific effects of Ya-Hom on cAMPdependent phosphorylation of LASP1 in the parietal cell. Cells were isolated from rabbit gastric mucosae using sequential pronase/collagenase digestion then enriched to $80-90 \%$ purity using Optiprep step gradients as previously described ${ }^{19}$. Primary cultures of enriched parietal cells were maintained on Matrigel-coated glass-bottomed 35-mm dishes in a complete medium [1:1 mixture of Ham's F-12 and DMEM, pH 7.4; BSA $(2 \mathrm{mg} / \mathrm{ml})$, epidermal growth factor $(50 \mathrm{ng} / \mathrm{ml})$, hydrocortisone $(10 \mathrm{nM})$, insulin $(5 \mu \mathrm{g} / \mathrm{ml})$, transferrin $(5 \mu \mathrm{g} / \mathrm{ml})$, sodium selenite $(5 \mathrm{ng} / \mathrm{ml})$, Novobiocin $(50 \mu \mathrm{g} / \mathrm{ml})$ and gentamicin sulfate $(100 \mu \mathrm{g} / \mathrm{ml})]^{22}$.

\subsection{Measurement of intracellular free calcium $\left(\left[\mathrm{Ca}^{2+}\right] \mathrm{i}\right)$ responses in primary cultures of parietal cells}

Changes in $\left[\mathrm{Ca}^{2+}\right]$ i were measured with fura-2 using a dual-wavelength excitation ratio technique as previously described ${ }^{23,24}$. Parietal cells in primary culture were loaded with fura- 2 by incubating in culture medium [1:1 mixture of Ham's F-12 and DMEM, $\mathrm{pH}$ 7.4 , without bicarbonate; $\mathrm{BSA}(2 \mathrm{mg} / \mathrm{ml})$ ] containing the cell-permeant form (fura-2 AM, $4 \mu \mathrm{M}$ ) for $30 \mathrm{~min}$ in a humidified $37^{\circ} \mathrm{C}$ air incubator. Cells were then rinsed twice with culture medium and placed in the incubator for $15 \mathrm{~min}$ before addition of various agents. Ya-hom $(10 \mathrm{mg} / \mathrm{ml})$ or DMSO vehicle were added 5-20 min prior to carbachol $(10 \mu \mathrm{M})$ or thapsigargin $(3 \mu \mathrm{M})$. In experiments with thapsigargin and ionomycin, the latter agent $(10 \mu \mathrm{M})$ was added after the thapsigargin-induced rise in $\left[\mathrm{Ca}^{2+}\right] \mathrm{i}$ was observed. Images acquired at $340 / 380 \mathrm{~nm}$ excitation, $510 \mathrm{~nm}$ emission wavelengths were digitized and analyzed with Openlab software (Agilent). Calcium binding to fura- 2 increases the fluorescent signal, the intensity of which is traditionally displayed as a range of pseudo-color shades with blue representing low $\left[\mathrm{Ca}^{2+}\right] \mathrm{i}$ and yellow to red representing high $\left[\mathrm{Ca}^{2+}\right] \mathrm{I}^{29}$. This format was used in the present study as well.

\subsection{LASP1 phosphorylation assay}

LASP1 is a highly conserved, actin-associated phosphoprotein that has been linked to acid secretory regulation in a knockout mouse mode ${ }^{30}$ and shown to undergo increased phosphorylation in parietal cells following histamine stimulation ${ }^{25,26,28,30}$. Increased LASP1 phosphorylation is mediated via the cAMP signaling pathway ${ }^{25}$. Alterations in LASP1 phosphorylation are readily detected in the form of an apparent molecular weight (Mr) "band shift" on Western blots using a specific monoclonal LASP1 antibody (8C6) that we engineered ${ }^{25}$ and which now commercially available from several companies including, VWR, Fisher, Merck and Sigma. The 8C6 antibody recognizes both phosphorylated and non-phosphorylated forms of LASP $1^{25}$.

To detect changes in LASP1 phosphorylation, isolated gastric glands or parietal cells were incubated in medium B with and without Ya-hom $(10 \mathrm{mg} / \mathrm{ml}$, $37^{\circ} \mathrm{C}, 30 \mathrm{~min}$ ) then stimulated with forskolin for 15 min. Glands or cells were centrifuged and supernates discarded. Resultant pellets were washed with cold PBS and heated in SDS/BME solution (0.3\% SDS and $1 \% \beta$ mercaptoethanol, $100^{\circ} \mathrm{C}, 3 \mathrm{~min}$ ). Dissolved protein was subjected to SDS-PAGE followed by Western blot analysis on nitrocellulose using the LASP1 monoclonal antibody, $8 \mathrm{C}^{25}$, and ECL detection. As discussed above, the phosphorylated form of LASP1 is readily detected on Western blot based on an upward Mr "band shift"25.

\subsection{Statistical analyses}

Parametric data were expressed as means \pm SE. Multiple comparisons were analyzed by ANOVA and Tukey-Kramer pos-hoc test with the use of a computer program Instat 2.03. Differences were considered statistically significant when the $P$ value was $<0.05$.

\section{RESULTS}

\subsection{Effect of Ya-hom on carbachol-stimulated AP accumulation in gastric glands}

Lower concentrations of Ya-hom $(10,15 \mathrm{mg} / \mathrm{ml})$ had no significant effect on basal AP accumulation in gastric glands $(24.6 \pm 1.1,29.9 \pm 1.6$, and $27.4 \pm 1.7$ respectively). However, $20 \mathrm{mg} / \mathrm{ml}$ Ya-hom did elicit a small, but significant increase in AP accumulation (36.3 2.7 ).

As previously shown ${ }^{31}$, carbachol stimulates gastric gland AP accumulation in a biphasic, timedependent manner that peaks at $15 \mathrm{~min}$ in response to a $10 \mu \mathrm{M}$ dose (Figure 1). Ya-hom $(10 \mathrm{mg} / \mathrm{ml})$ suppressed carbachol-stimulated AP accumulation at all time points sampled; however, this inhibition reached statistical significance only at 15 and $30 \mathrm{~min}$. Maximal inhibition occurred $15 \mathrm{~min}$ after carbachol addition $(53.1+13.0 \mathrm{vs}$ 103.3 \pm 17.9; Figure 1) and was dose-dependent (Figure 2). When gastric glands were preincubated with Ya-hom 
(30 min, $5 \mathrm{mg} / \mathrm{ml}$ and higher concentrations), carbacholstimulated AP accumulation was significantly inhibited. This inhibitory effect was most pronounced when Yahom was added $30 \mathrm{~min}$ prior to carbachol $(51.1 \pm 2.7 \%$ of the response to $10 \mu \mathrm{M}$ carbachol); however, Ya-hom also significantly inhibited the cholinergic response when added simultaneously with or 5 min after carbachol $(71.2 \pm 6.1 \%$ and $78.2 \pm 5.9 \%$ of the response to $10 \mu \mathrm{M}$ carbachol, respectively) (Figure 3).

\subsection{Effect of Ya-hom on the calcium signaling pathway in parietal cells}

As previously reported ${ }^{26}$, we confirmed that carbachol $(10 \mu \mathrm{M})$ increases intracellular free calcium in parietal cells in primary culture. Figure 4 depicts a representative experiment in which parietal cell responses to carbachol and effects of Ya-hom can be observed. Overall, $92.1 \%$ of observed parietal cells (representing a total of 38 cells sampled) responded to stimulation with $10 \mu \mathrm{M}$ carbachol. Ya-hom preincubation for $20 \mathrm{~min}$ led to a small increase in $\left[\mathrm{Ca}^{2+}\right] \mathrm{i}$ but no further increase was elicited by carbachol in any of sampled cells $(\mathrm{n}=38)$. Approximately $20 \%$ of parietal cells that were incubated with Ya-hom for less than 15 min responded to carbachol with a small increase in intracellular free calcium which was consistently lower than responsive control cells (data not shown).

\subsection{Effect of Ya-hom on histamine-stimulated AP accumulation in gastric glands}

Ya-hom significantly potentiated the stimulatory effect of histamine $(1 \mu \mathrm{M})$ on AP accumulation in a dose-dependent manner $(5,10$ and $20 \mathrm{mg} / \mathrm{ml}$; Figure $5)$. At the highest concentration tested $(20 \mathrm{mg} / \mathrm{ml})$, Yahom potentiation of the AP response was $200.5+58.9 \%$ greater than the response to $1 \mu \mathrm{M}$ histamine alone. In the presence of the histamine $\mathrm{H}_{2}$ receptor antagonist, cimetidine $(10 \mu \mathrm{M}), 10 \mathrm{mg} / \mathrm{ml}$ Ya-hom also potentiated the stimulatory effect of the adenylyl cyclase activator, forskolin, on gastric gland AP accumulation (Figure 6). Furthermore, as shown in Figure 6, preincubation of glands with Ya-hom for 30 min induced a leftward shift in the forskolin dose response curve $(0.1-10 \mu \mathrm{M})$.

\subsection{Effect of Ya-hom on forskolin-stimulated LASP1 phosphorylation}

Because Ya-hom potentiated forskolin-stimulation when tested across a wide range of forskolin concentrations and had no stimulatory effect on AP accumulation ratios in the presence of the $\mathrm{H}_{2}$-receptor antagonist, cimetidine, we concluded that this action was not associated with Ya-hom-induced elevation of [cAMP]i. To determine if Ya-hom might modulate other known downstream events within the cAMP signaling

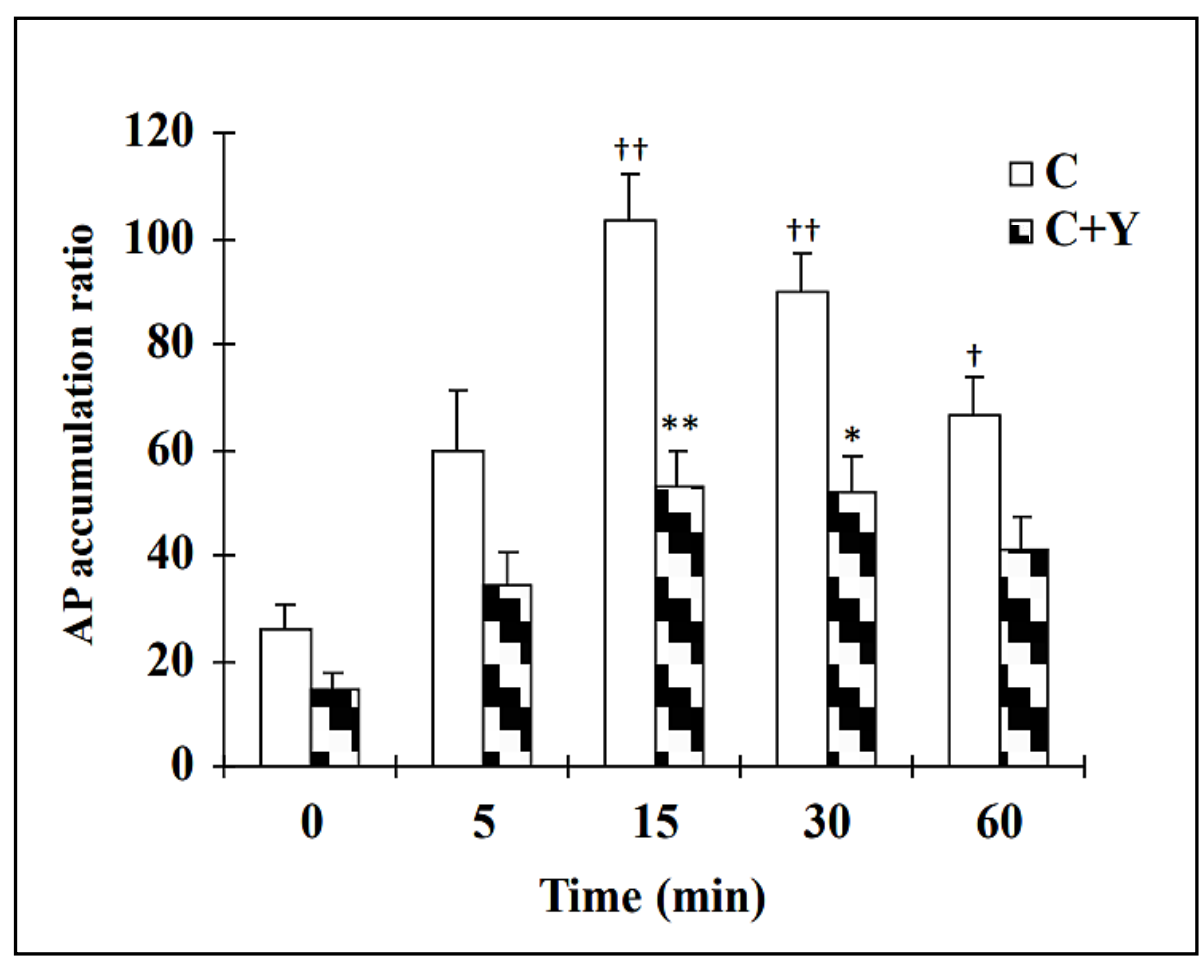

Figure 1. Time course of the effect of Ya-hom on carbachol-stimulated gastric gland AP accumulation. Isolated gastric glands were incubated $\left(37^{\circ} \mathrm{C}, 30 \mathrm{~min}\right)$ in the presence of the $\mathrm{H}_{2}$ receptor antagonist, cimetidine $(10 \mu \mathrm{M})$ with or without Ya-hom $(\mathrm{Y}, 10 \mathrm{mg} / \mathrm{ml}$, filled bars). Glands were removed for assay at $t_{0}$. Carbachol $(\mathrm{C}, 10 \mu \mathrm{M})$ was then added and samples taken for measurement of AP accumulation at indicated time points. Values were expressed as means + SEMs of 4 gland preparations isolated from 4 different rabbits. $\dagger P<0.05$ vs carbachol+cimetidine at time 0 , $\dagger \dagger P<0.001$ vs carbachol+cimetidine at time $0, * P<0.05$ vs carbachol+cimetidine at $30 \mathrm{~min} ; * * P<0.001$ vs carbachol+cimetidine at 15 min. 


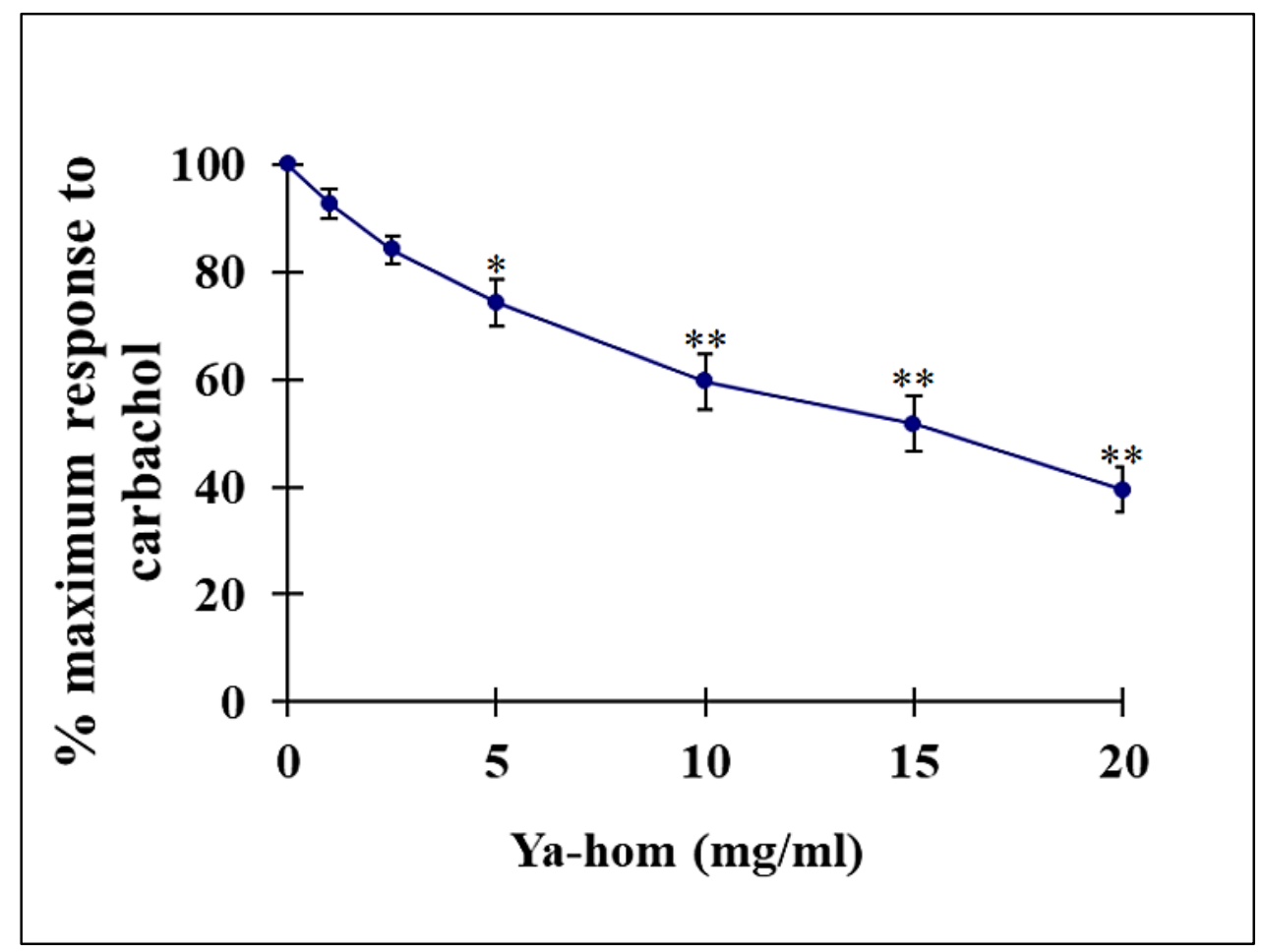

Figure 2. Dose response curve of Ya-hom inhibition of carbachol-stimulated gastric gland AP accumulation. As in figure 1, glands were preincubated with cimetidine $(10 \mu \mathrm{M})$ in the absence (control) or presence of Ya-hom $(1,2.5,5,10,15 \mathrm{and} 20 \mathrm{mg} / \mathrm{ml})$ at $37^{\circ} \mathrm{C}$ for $30 \mathrm{~min}$ before adding carbachol $(10 \mu \mathrm{M})$. AP accumulation ratios are expressed as $\%$ response to $10 \mu \mathrm{M}$ carbachol $(58.1 \pm 14.4)$ and are means \pm SEMs of 5 gland preparations from 5 different rabbits. $* P<0.01$ vs control, $* * P<0.001$ vs control.

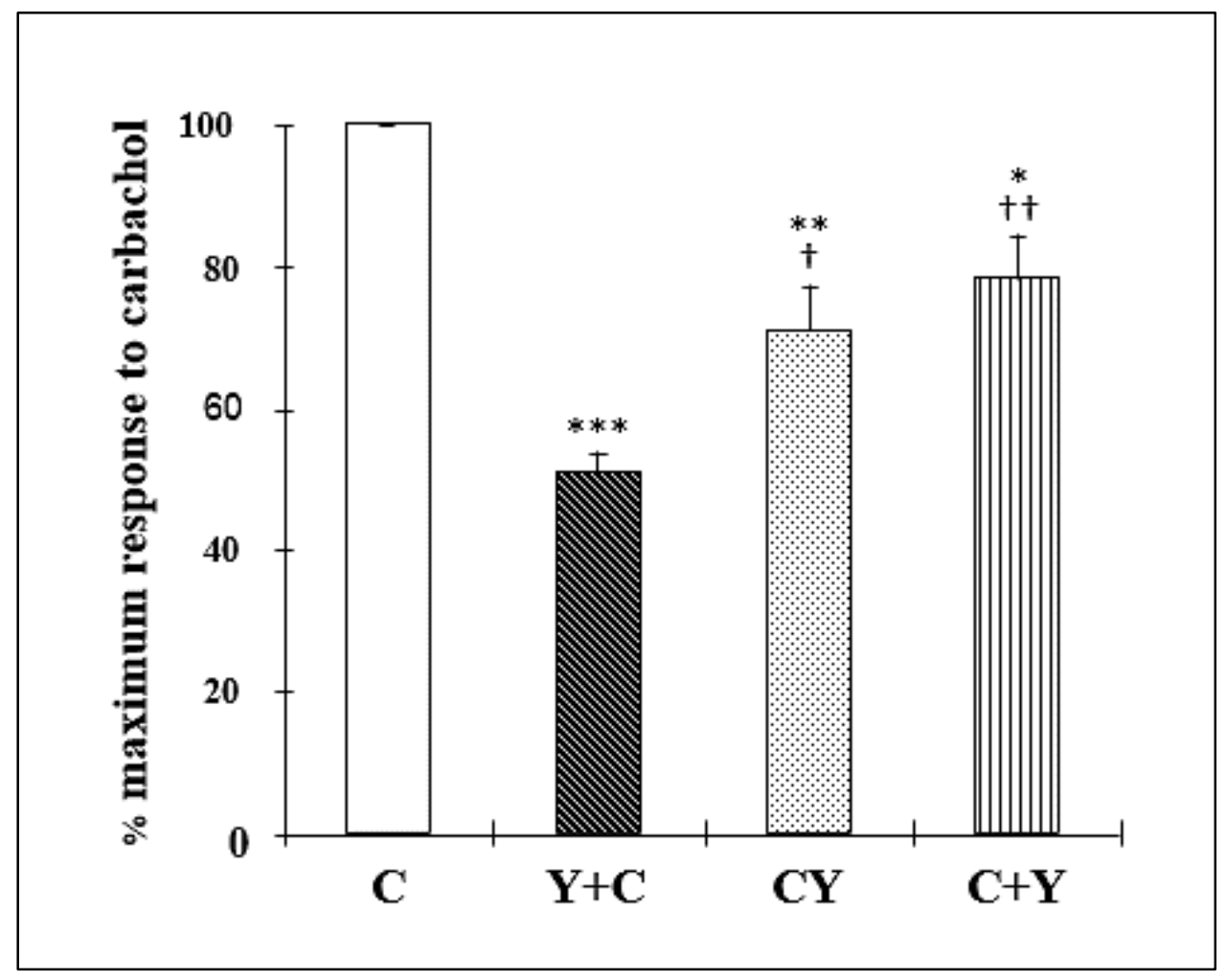

Figure 3. Effect of sequential addition of Ya-hom and carbachol on gastric gland AP accumulation. Cimetidine (10 $\mu \mathrm{M})$ was added to all flasks 30 min prior to addition of carbachol $(10 \mu \mathrm{M})$ and Ya-hom $(10 \mathrm{mg})$. Samples were collected 15 min after carbachol addition. C, carbachol; (Y+C) 30 min preincubation with Ya-hom; (CY) Simultaneous addition of Ya-hom and carbachol; (C+Y) Ya-hom added 5 min after carbachol. AP accumulation ratios are expressed as $\%$ response to $10 \mu \mathrm{M}$ carbachol $(\mathrm{C})$ and expressed as means \pm SEMs of 4 gland preparations from 4 different rabbits. $* P<0.01$ vs $\mathrm{C}, * * P<0.01$ vs $\mathrm{C}, * * * P<0.001$ vs $\mathrm{C} . \dagger P<0.5$ vs $\mathrm{Y}+\mathrm{C}, \dagger \dagger P<0.01$ vs $\mathrm{Y}+\mathrm{C}$. 


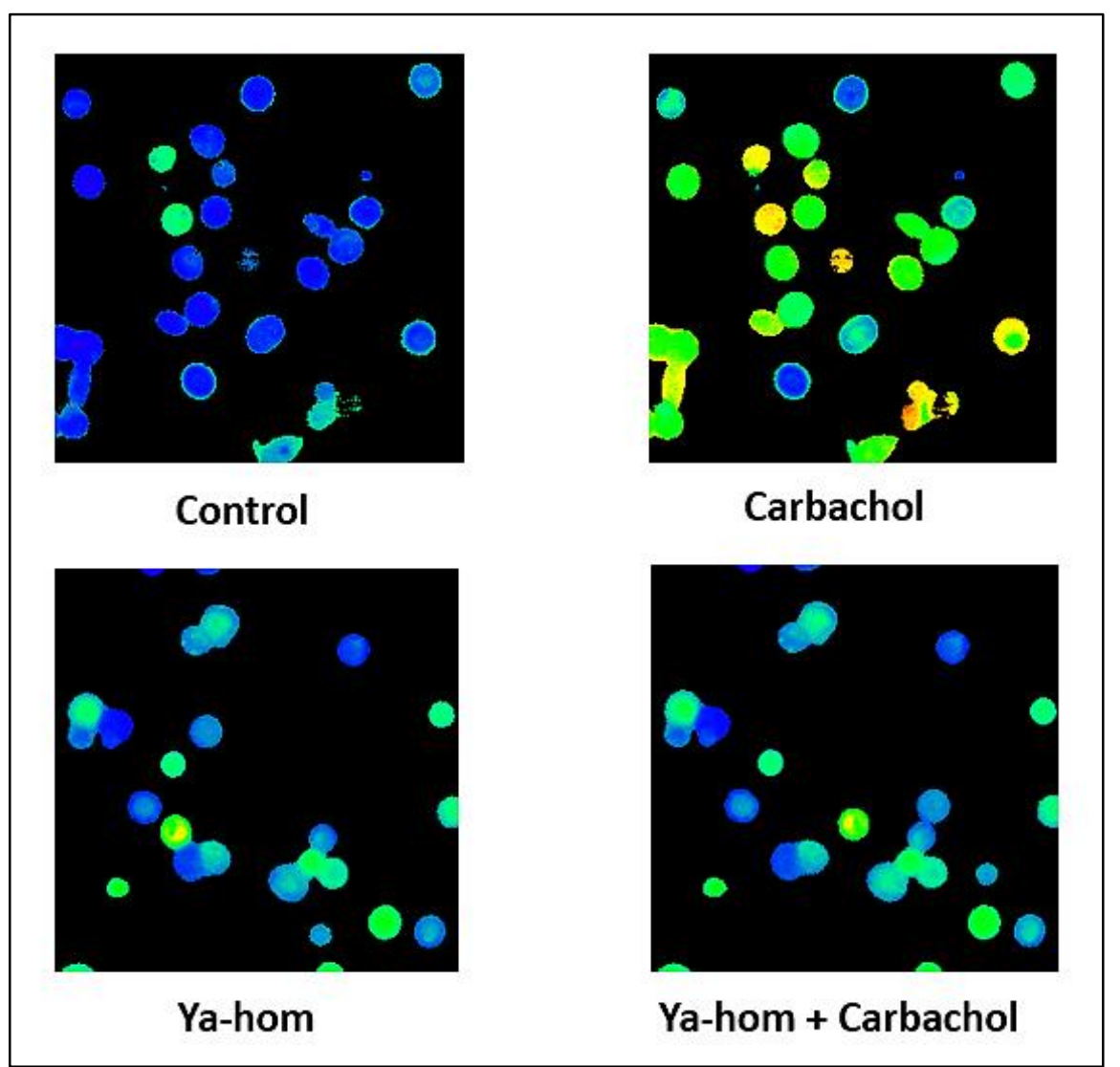

Figure 4. Ya-hom inhibits carbachol-stimulated increases in intracellular free calcium in parietal cells in primary culture. Cells were loaded with the fluorescent $\left[\mathrm{Ca}^{2+}\right]$ i indicator, fura2, as described in Methods. Carbachol $(10 \mu \mathrm{M})$ addition led to an increase in $\left[\mathrm{Ca}^{2+}\right] \mathrm{i}$ in $92.1 \%$ of control parietal cells (38 cells). Preincubation of Ya-hom $(10 \mathrm{mg} / \mathrm{ml})$ for $20 \mathrm{~min}$ inhibited the response of all observed parietal cells (38 cells) to carbachol stimulation. Similar results were observed in 3 independent experiments.

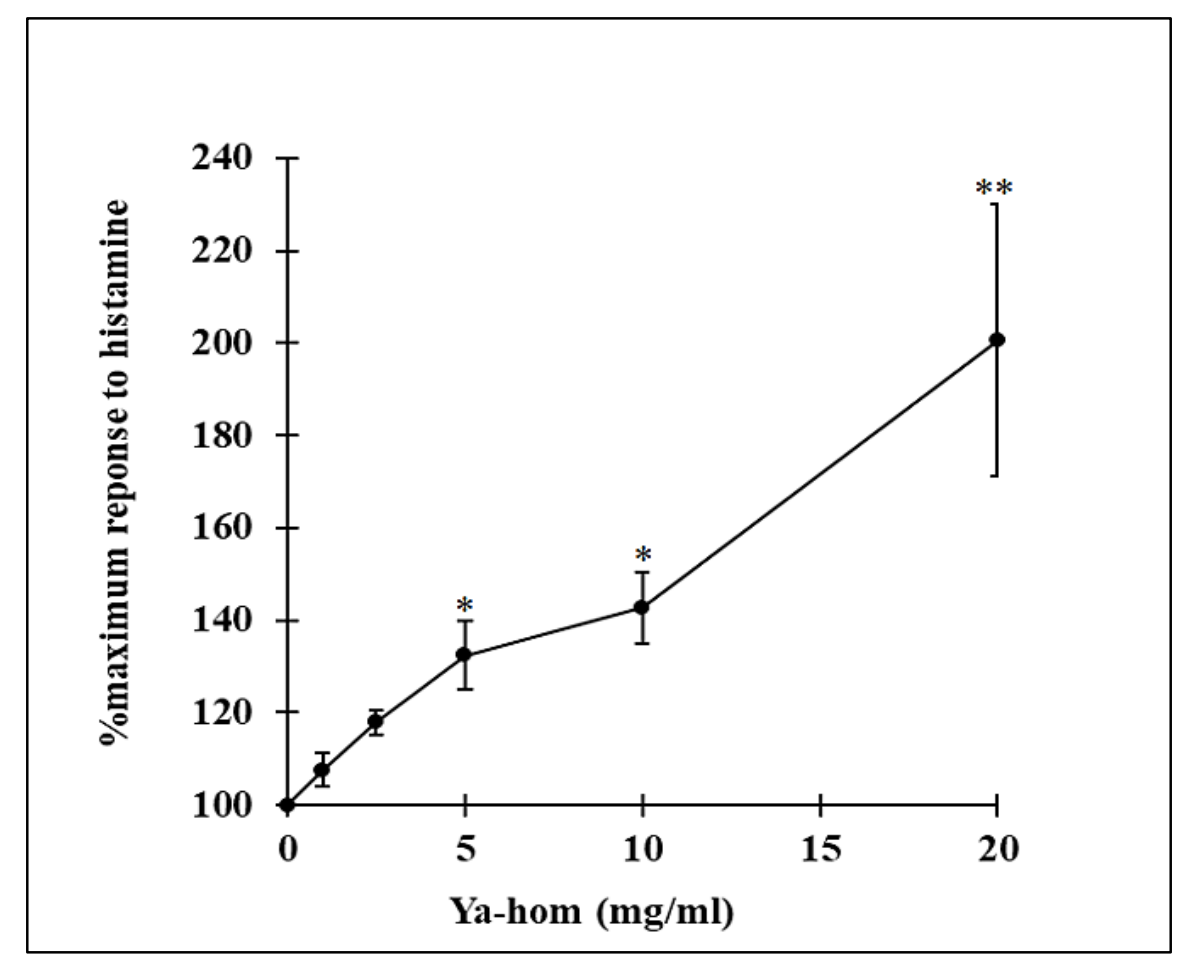

Figure 5. Dose-dependent effects of Ya-hom potentiation of histamine-stimulated gastric gland AP accumulation. Isolated gastric glands were incubated in the absence (control) and in the presence of Ya-hom $\left(1,2.5,5,10\right.$ and $20 \mathrm{mg} / \mathrm{ml}$ ) at $37^{\circ} \mathrm{C}$ for 30 min before adding histamine (1 $\mu \mathrm{M})$. AP accumulation ratios were calculated as $\%$ response to $1 \mu \mathrm{M}$ histamine $(128.9 \pm 11.2)$ and expressed as means \pm SEMs of 4 gland preparations isolated from 4 different rabbits. $* P<0.05$ vs control, $* * P<0.001$ vs control. 


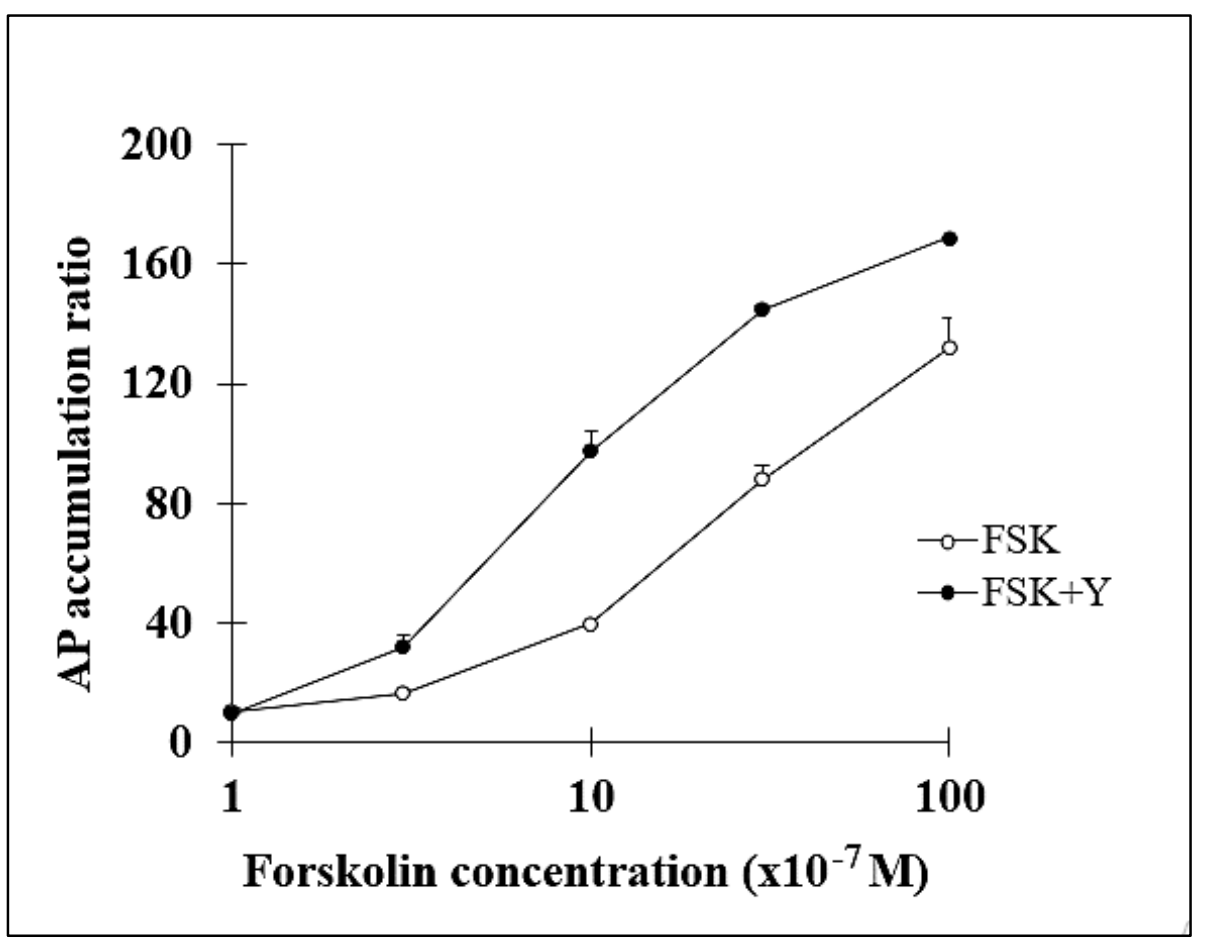

Figure 6. Effect of Ya-hom on dose-dependent forskolin-stimulated AP accumulation. Isolated gastric glands were preincubated with the $\mathrm{H}_{2}$ receptor antagonist, cimetidine $\left(10 \mu \mathrm{M}, 37^{\circ} \mathrm{C}, 30 \mathrm{~min}\right)$, along with Ya-hom where indicated $(\mathrm{Y}, 10 \mathrm{mg} / \mathrm{ml}$, closed circles). Forskolin (FSK) was then added at indicated concentrations. AP accumulation ratios were determined $15 \mathrm{~min}$ after adding forskolin and expressed as means \pm SEMs of 3 gland preparations from 3 different rabbits. $* P<0.001$ vs forskolin alone.

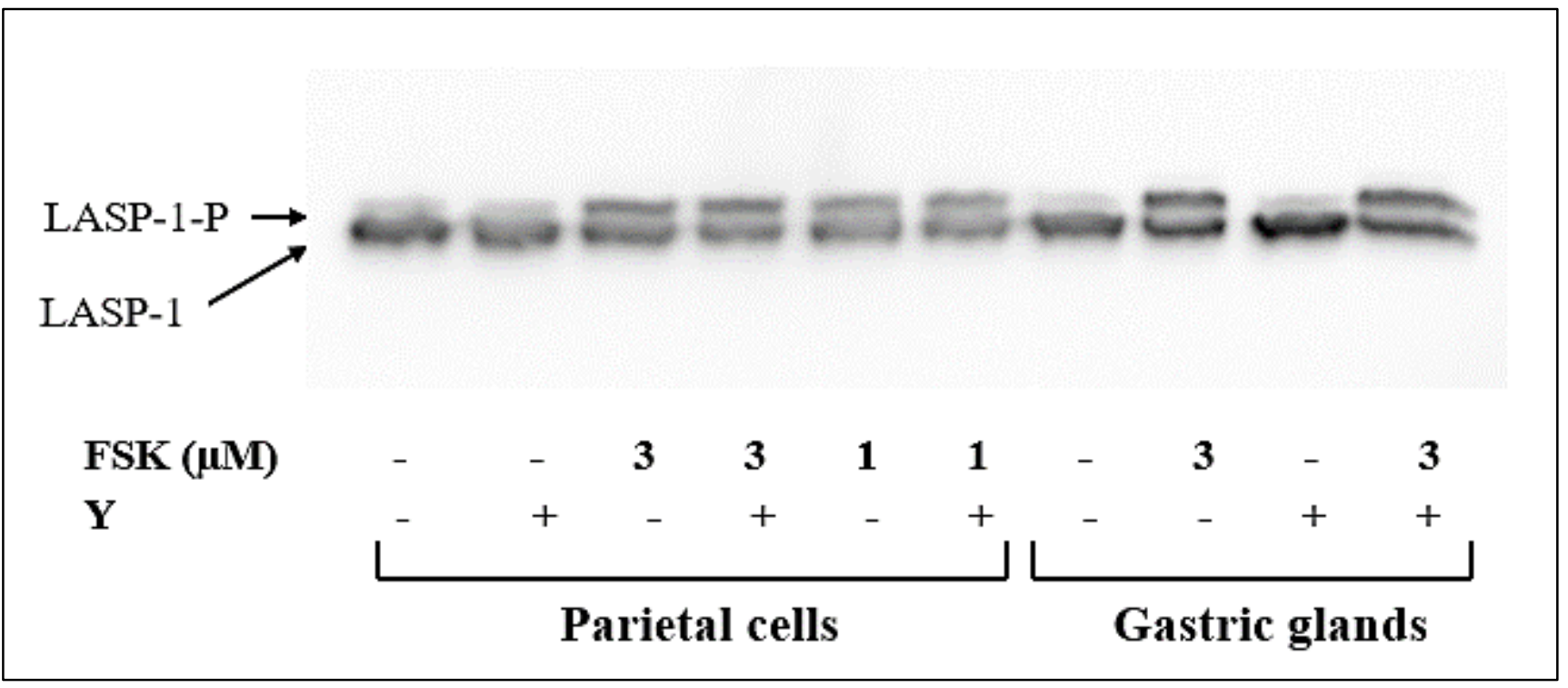

Figure 7. Western blot of parietal cell and isolated gastric gland extracts showing that Ya-hom has no effect on basal or forskolin-stimulated LASP1 phosphorylation. Parietal cells or gastric glands from two different rabbits were incubated with Ya-hom (YH, $10 \mathrm{mg} / \mathrm{ml})$ for $30 \mathrm{~min}$ prior to forskolin (FSK) stimulation. Forskolin is a specific activator of adenylyl cyclase known to increase [cAMP]i and activate PKA. In parietal cells, both forskolin and histamine are known to elevate [cAMP]i and this increase in cAMP levels has been linked to increased phosphorylation of the actin-associated protein, LASP1. Increased phosphorylation of Lasp1 can be identified based on an apparent Mr "band shift" (arrow).

pathway, we examined its effects on LASP1 phosphorylation as well as F-actin redistribution. LASP1 is a previously identified substrate for cAMP-dependent protein kinase (PKA), and the phosphorylation of this protein is correlated with histamine-stimulated, cAMPdependent activation of acid secretion ${ }^{28}$. The specific adenylyl cyclase activator, forskolin, similarly increases intracellular cAMP, activates PKA and increases LASP1 phosphorylation in parietal cells ${ }^{25}$. When LASP1 is phosphorylated, the response can be readily detected (using a previously characterized LASP1 mab, 8C6) as an apparent $\mathrm{Mr}$ band shift on Western blot ${ }^{28}$. These 
findings are recapitulated in Figure 7 wherein incubation of highly enriched parietal cells or gastric glands with forskolin can be seen to induce a dose-dependent Mr band shift in LASP1 immunoreactivity. Incubation of parietal cells or gastric glands with Ya-hom for 30 min prior to forskolin stimulation did not alter LASP1 phosphorylation (Figure 7).

\subsection{Effect of Ya-hom on forskolin-stimulated parietal cell $\mathbf{F}$-actin distribution.}

Stimulation of parietal cells with cAMPdependent agonists is also known to elicit dramatic morphological changes associated with F-actin redistribution in parietal cells ${ }^{32}$. To determine if Ya-hom alters F-actin distribution, control and forskolin-stimulated parietal cells were visualized by immunofluorescent staining with Oregon green-labelled phalloidin. As shown in Figure 8, Ya-hom had no detectable effect on F-actin distribution in either control or forskolinstimulated parietal cells.

\subsection{Effect of Ya-hom on the parietal cell response to thapsigargin and ionomycin.}

Since we found no evidence for upstream or known downstream effects of Ya-hom on the cAMP signaling pathway, we tested for effects on the calcium signaling pathway that might explain the potentiating effect of Ya-hom. Thapsigargin, which is an inhibitor of ATPase-dependent uptake of $\mathrm{Ca}^{2+}$ into intracellular stores, was previously shown to elevate parietal cell $\left[\mathrm{Ca}^{2+}\right]_{\mathrm{i}}$ and to potentiate histamine and forskolin stimulating $\mathrm{HCl}$ secretion ${ }^{33}$. In the present study, Ya-hom was found to elicit a small increase in $\left[\mathrm{Ca}^{2+}\right]_{i}$, thus, it was possible that Ya-hom induces a slow release of $\mathrm{Ca}^{2+}$ from intracellular stores and this $\mathrm{Ca}^{2+}$ release is responsible for the potentiation of cAMP-induced secretory response. If this were the case, then Ya-hom would be expected to suppress thapsigargin-induced release of $\mathrm{Ca}^{2+}$ from intracellular stores by depleting these stores. As expected, both thapsigargin $(3 \mu \mathrm{M})$ and ionomycin $(10 \mu \mathrm{M}), \mathrm{a} \mathrm{Ca}^{2+}$ ionophore, increased intracellular free calcium levels in fura-2 loaded parietal cells (Figure 9). When cells were preincubated with Ya-hom $(10 \mathrm{mg} / \mathrm{ml}, 20 \mathrm{~min})$, the thapsigargin-induced elevation in $\left[\mathrm{Ca}^{2+}\right]_{\mathrm{i}}$ was indeed significantly suppressed. In contrast, Ya-hom had no significant effect on ionomycin-induced elevation of $\left[\mathrm{Ca}^{2+}\right]_{\text {. }}$ Notably, Ya-hom and thapsigargin had a similar potentiating effect on histamine-stimulated AP accumulation (Figure 10). In addition, the effects of Ya-hom and thapsigargin on histamine-stimulated AP accumulation were not additive, suggesting the possibility that both agents were affecting intracellular calcium storage mechanisms. Potential sites of Ya-hom action are summarized in Figure 11.

\section{DISCUSSION}

Previously, a water-based extract of Ya-hom was found to inhibit both histamine- and carbacholstimulated secretion of gastric acid, pepsin and soluble mucus but to potentiate visible mucus secretion in gastric fistula rats. Maximal inhibition of histamine and carbachol-stimulated gastric acid secretion was detected at $4 \mathrm{~g} / \mathrm{kg}$ Ya-hom $(45.5 \%$ and $53.8 \%$ respectively). Further increases in Ya-hom $(8 \mathrm{mg} / \mathrm{kg})$ did not alter the inhibitory effect ${ }^{12}$. In isolated mouse whole stomach, Ya-hom, at a concentration of $10 \mathrm{mg} / \mathrm{ml}$, also inhibited gastric acid secretion stimulated by histamine and cholinergic agonist, bethanechol ${ }^{13}$. In the present study, we expanded our investigations to analyze the effects of Ya-hom at the level of the parietal cell. Using a similar water-soluble extract, we found that Ya-hom inhibited carbachol-stimulated AP accumulation in gastric glands with a maximum inhibition of $60 \%$ at a dose of $20 \mathrm{mg} / \mathrm{ml}$, a finding that is similar to previous observations in gastric fistula rats ${ }^{12}$. Alterations in the sequential addition of Ya-hom and carbachol revealed that preexposure to Ya-hom is required to elicit maximal inhibition.

Ya-hom alone, at doses of 10 and $15 \mathrm{mg} / \mathrm{ml}$ appeared to elicit small increases in basal AP accumulation in isolated gastric glands; however, this effect was significant only at the highest dose tested $(20 \mathrm{mg} / \mathrm{ml})$. We hypothesized that Ya-hom might initiate the release of small amount(s) of histamine from ECL cells within gastric glands, thereby leading to the observed increase in "basal" AP accumulation. This hypothesis is supported by observations that there was a small decrease in AP accumulation when Ya-Hom was added along with the specific $\mathrm{H}_{2}$ receptor antagonist, cimetidine (Figure 1). However, because the apparent effects of Ya-hom on basal AP accumulation are quite small, we cannot yet conclude that Ya-hom induces the release of endogenous histamine from ECL cells, nor can the effect of Ya-hom on other endogenous mediators be excluded.

In direct contrast to the inhibitory effect of Yahom on carbachol, this agent enhanced the stimulatory effect of histamine on AP accumulation. Ya-hom also potentiated forskolin-stimulated AP accumulation in the presence of histamine $\mathrm{H}_{2}$ receptor antagonist, cimetidine, an observation that supports an interaction between Ya-hom and downstream events within the cAMP signaling pathway.

Although Ya-hom had no effect on forskolinstimulated LASP1 phosphorylation, an effect on PKAdependent phosphorylation events cannot be entirely ruled out, as a modulatory action on other, as yet unidentified, PKA substrates is possible. The site of Ya-hom action may also be further downstream of $\mathrm{H}_{2}$ receptor- and PKA-dependent activation events. However, based on our observations that Ya-hom does not alter F-actin 

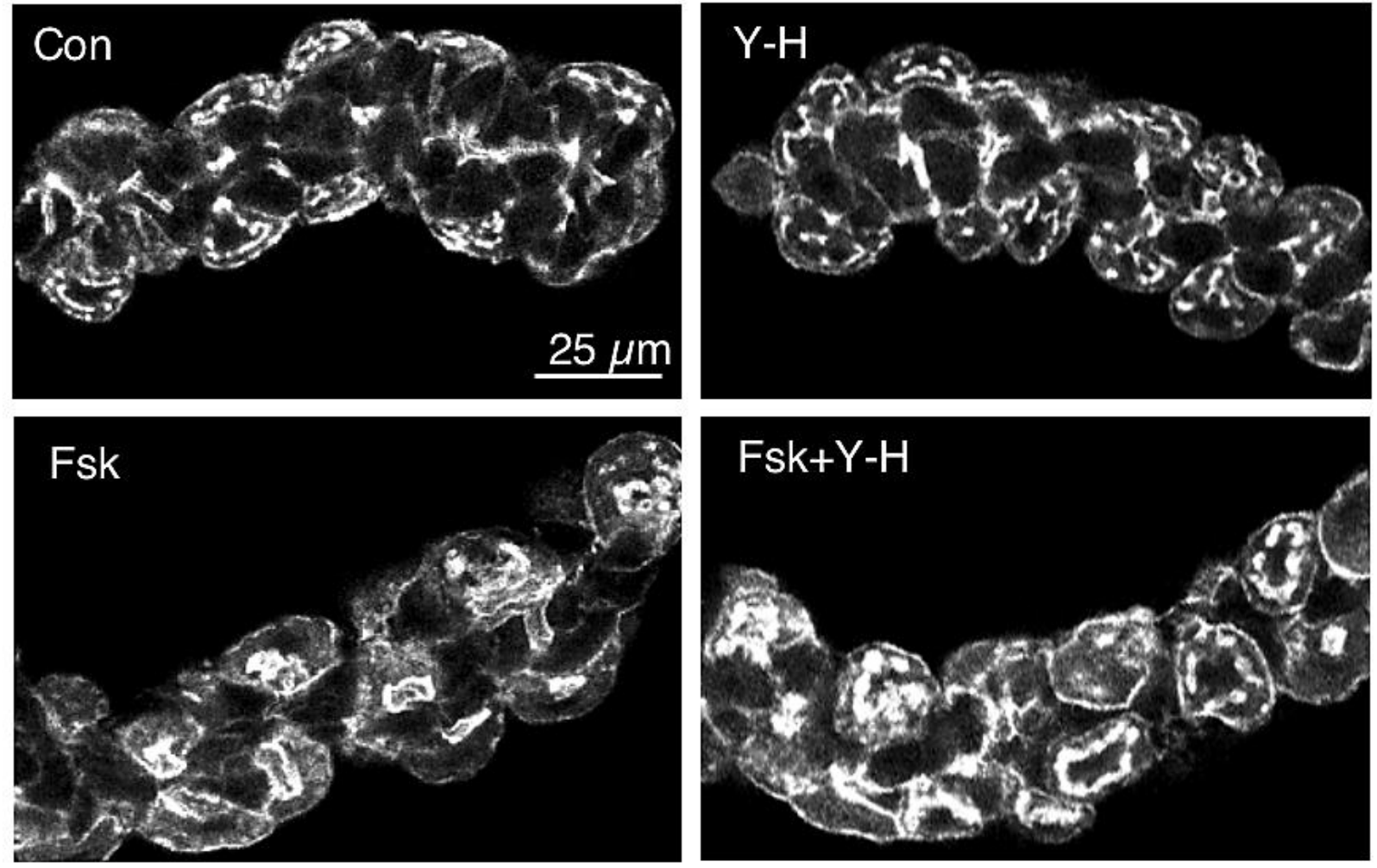

Figure 8. Ya-hom has no effect on basal or forskolin-stimulated F-actin distribution. Gastric glands were preincubated with and without Yahom (Y-H) for $30 \mathrm{~min}$. A portion were stimulated with forskolin (Fsk, $10 \mu \mathrm{M}, 15 \mathrm{~min}$ ). Con, DMSO vehicle. F-actin distribution were analyzed in paraformaldehyde-fixed Oregon Green phalloidin-stained glands by confocal microscopy.

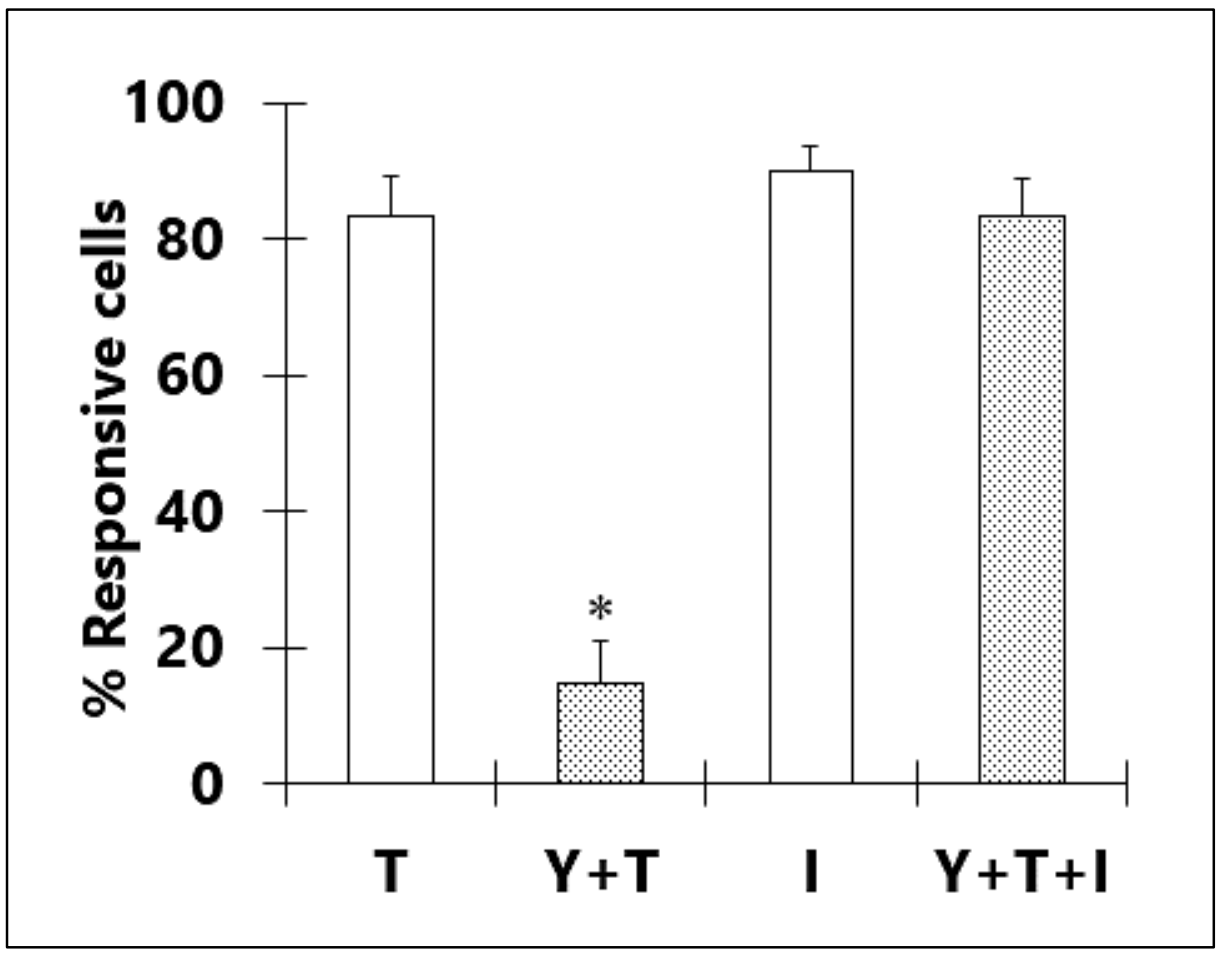

Figure 9. Effect of Ya-hom on thapsigargin and ionomycin-induced an increase in intracellular free calcium. Fura2-loaded parietal cells were preincubated with and without Ya-hom $(\mathrm{Y}, 10 \mathrm{mg} / \mathrm{ml})$ for $20 \mathrm{~min}$ prior to thapsigargin $(\mathrm{T}, 3 \mu \mathrm{M})$ addition. Ionomycin (I, $10 \mu \mathrm{M})$ was added immediately after thapsigargin's effect had been observed $(\mathrm{Y}+\mathrm{T}+\mathrm{I})$. Values are calculated as \% responsive cell of total observed cells and expressed as means + SEMs of 6 independent experiments. $* P<0.001$ vs thapsigargin alone. 


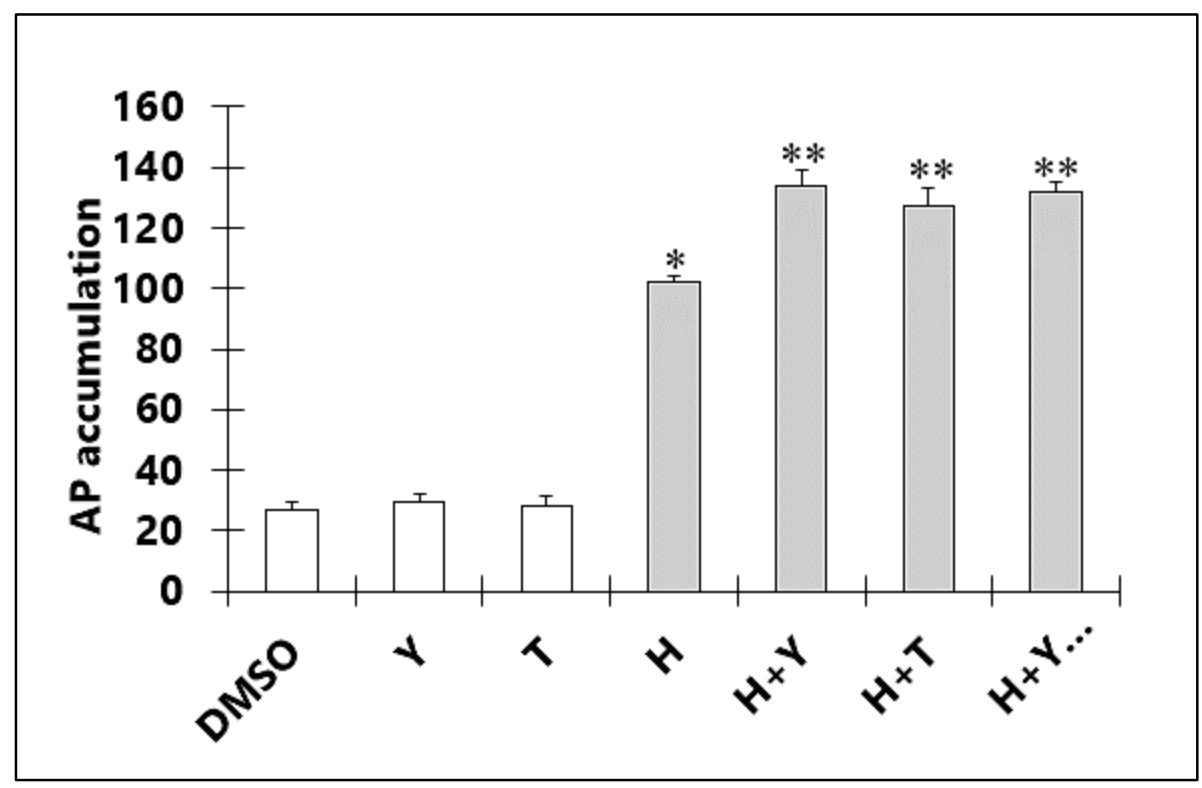

Figure 10. Effects of Ya-hom and thapsigargin on histamine-stimulated gastric gland AP accumulation. Isolated gastric glands were incubated with and without of Ya-hom $\left(\mathrm{Y}, 10 \mathrm{mg} / \mathrm{ml}, 37^{\circ} \mathrm{C}, 30 \mathrm{~min}\right)$. As thapsigargin was dissolved in dimethylsulfoxide (DMSO, final concentration $0.1 \%)$, a similar concentration was added to all other flasks upon addition of thapsigargin (T, $3 \mu \mathrm{M})$ in order to control for possible non-specific effects of this vehicle. Where indicated, glands were stimulated with histamine $(\mathrm{H}, 1 \mu \mathrm{M}$, closed bars) for 30 min. AP accumulation ratios were expressed as means $\_$SEMs of 4 independent experiments. $* P<0.05$ vs DMSO control, $* * P<0.001$ vs DMSO control.

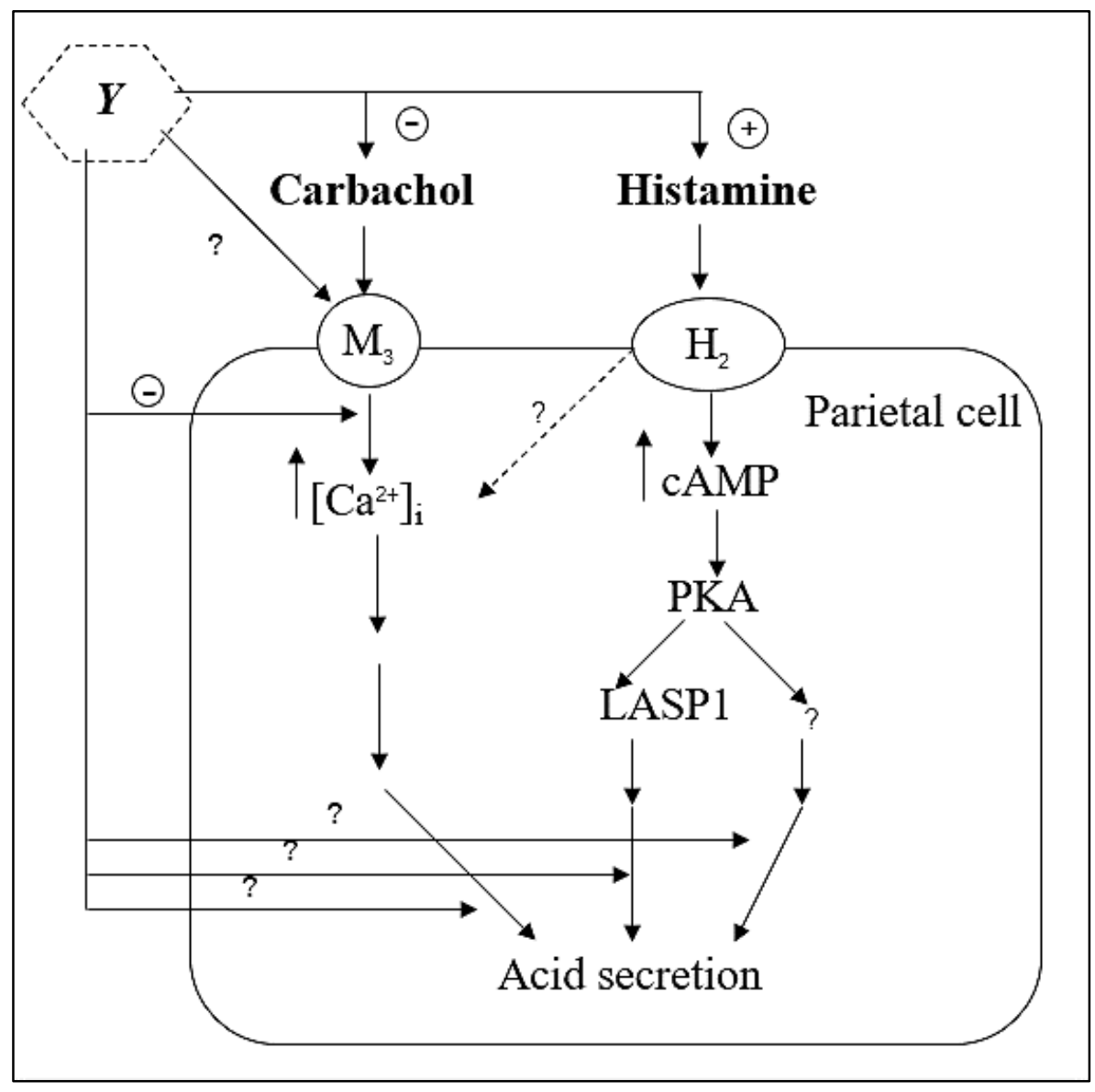

Figure 11. Schematic diagram depicting potential sites of Ya-hom actions on cAMP and $\mathrm{Ca}^{2+}$-dependent signaling pathways within the gastric parietal cell.

We hypothesize that Ya-hom modulates calcium release from intracellular storage sites, thereby suppressing the cholinergic response. However, this does not exclude the other possible mechanisms. Ya-hom may interact directly with the $\mathrm{M}_{3}$ muscarinic receptor. It may also act on sites parallel to or beyond PKA-dependent LASP1 phosphorylation or on other unknown calcium-regulated signaling events to potentiate acid secretion stimulated by histamine. 
distribution in control or forskolin-stimulated parietal cells, it is unlikely that Ya-hom directly affects the morphological changes that occur within the parietal cell following stimulation.

Several Ya-hom ingredients including $G$. glabra $^{34}$, A. lappa ${ }^{35}$, S. aromaticum ${ }^{9}$ and A. gramineus $^{11}$, have been found to decrease histamine-induced contraction of tracheal and ileal smooth muscle. Those reports do not contradict present findings because histamine effects on smooth muscle are mediated via $\mathrm{H}_{1}$ receptorlinked mechanisms whereas gastric parietal cell $\mathrm{HCl}$ secretion is regulated by the histamine $\mathrm{H}_{2}$ receptor subtype $^{36}$. This is an important distinction because both cholinergic $\mathrm{M}_{3}$ receptor $^{37}$ and histamine $\mathrm{H}_{1}$ receptor $^{36}$ subtype-linked activations are mediated via intracellular calcium signaling events rather than the cAMP-PKA pathway. Thus, Ya-hom may inhibit $\mathrm{H}_{1}$-receptor associated smooth muscle contraction by mechanisms similar to those associated with inhibition of cholinergic $\mathrm{M}_{3}$ receptor-mediated gastric acid secretion.

In is not surprising that Ya-hom could inhibit the effect of carbachol in our study as previously shown to inhibit carbachol stimulation in gastric fistula rats and to inhibit bethanechol stimulated $\mathrm{HCl}$ secretion in isolated mouse whole stomach. The effects of Ya-hom on cholinergic functions has not been studied in other organs; however, some Ya-hom ingredients including G. glabra $^{6,34}$, A. lappa $^{8,35}$, S. aromaticum $^{9,10}$ and A. gramineus $^{11}$, are known to relax tracheal and ileal smooth muscle by antagonizing acetylcholine. Since the muscarinic $\mathrm{M}_{3}$ receptor subtype plays an important role in regulating tracheal and ileal smooth muscle contraction as well as parietal cell acid secretion ${ }^{37,38}$, it is possible that Ya-hom's cholinergic antagonism involves effects on an $\mathrm{M}_{3}$ receptor subtype or its signal transduction pathway. The finding that Ya-hom not only inhibits carbachol-stimulated AP accumulation but also carbachol-induced elevation of $\left[\mathrm{Ca}^{2+}\right] \mathrm{i}$, suggests the possibility that Ya-hom interacts directly with parietal cell $\mathrm{M}_{3}$ muscarinic receptors. However, we believe this scenario to be unlikely because 1) Ya-hom required a pre-incubation period to exert a maximal inhibitory effect on carbachol-induced elevation in $\left[\mathrm{Ca}^{2+}\right] \mathrm{i}$ and 2 ) an inhibitory action on the $\mathrm{M} 3$ receptor does not explain Ya-hom-induced potentiation of the histamine-induced acid secretory response. Thus, we hypothesize that the site of the modulatory effects of Ya-hom action is intracellular, rather than at the membrane receptor level.

Because there is evidence that the welldocumented synergistic interactions of histamine and carbachol on parietal cell $\mathrm{HCl}$ secretion involves the release of calcium from intracellular storage $\operatorname{sites}^{39}$ and present observations that pre-incubation with Ya-hom induces a small increase in $\left[\mathrm{Ca}^{2+}\right] \mathrm{i}$. We hypothesized that the potentiating effect of Ya-hom on the histamine response might similarly involve alterations in intra- cellular calcium distribution. To investigate this possibility, we used two agents that are known to elevate $\left[\mathrm{Ca}^{2+}\right] \mathrm{i}$ by different mechanisms, thapsigargin and ionomycin. We found that preincubation of parietal cells with Ya-hom for at least 20 min led to inhibition of the thapsigargin-induced rise in $\left[\mathrm{Ca}^{2+}\right]$ i In contrast, shorter exposure times did not suppress this response (data not shown). Because thapsigargin is known to be an intracellular calcium storage pool $\mathrm{Ca}^{2+}$ ATPase inhibitor, our findings suggest that Ya-hom may induce a slow, time-dependent release of calcium from the same thapsigargin-regulated intracellular calcium storage site(s). In contrast, Ya-hom had no effect on the parietal cell calcium response to ionomycin, a calcium ionophore. These data suggest that Ya-hom does not directly affect the influx of extracellular calcium. Based on these findings, we postulate that Ya-hom may suppress cholinergic stimulation of parietal cell $\mathrm{HCl}$ secretion by modifying the release of calcium from intracellular storage sites.

It has been shown that thapsigargin-induced elevation in intracellular free calcium is not associated with an increase in acid secretion ${ }^{33}$. The present data confirm this observation and further show that Ya-hom similarly has no independent effect on basal AP accumulation in the presence of $\mathrm{H}_{2}$ receptor antagonists. In contrast, both Ya-hom and thapsigargin potentiated histamine-stimulated AP accumulation to the same extent, with no further increase when they were added simultaneously. These combined data suggest that Yahom and thapsigargin may work through similar mechanisms. Thapsigargin can stimulate acid secretion when added together with phorbol ester, a protein kinase C (PKC) activator ${ }^{33}$, and there is evidence to suggest that calcium-independent PKC isoforms are involved in mediating the acid secretory response to carbachol ${ }^{40}$. Thus, the ability of Ya-hom to enhance cAMP-dependent secretagogue effects may also involve the activation of calcium-independent signal transduction pathways. Alternatively, a low-level release of calcium from agonist-sensitive intracellular stores may be sufficient to explain the ability of Ya-hom to potentiate histamine and forskolin-stimulated acid secretory responses.

\section{CONCLUSION}

Our findings suggest that Ya-hom attenuates carbachol-stimulated gastric gland AP accumulation by slowly releasing calcium from agonist-sensitive intracellular pool(s), thereby suppressing the cholinergic response. In contrast, a Ya-Hom induced rise in intracellular free calcium may potentiate histamine and forskolin-stimulated gastric gland acid secretory responses. The synergistic interaction between Ya-hom and histamine in isolated gastric glands is in direct contrast to the inhibitory effects of this agent on 
histamine-stimulated acid secretion in gastric fistula rats and isolated mouse whole stomach. These conflicting observations may be explained by additional actions of Ya-hom on vagally-mediated acetylcholine release and/or other enteric mediators. Ya-hom might also induce the release of gastric inhibitory hormones such as somatostatin, thereby causing the inhibition of gastric secretion. Our findings suggest the possibility that combined use of Ya-hom with $\mathrm{H}_{2}$-receptor antagonist drugs will be more beneficial for inhibiting gastric secretion than a Ya-hom-antimuscarinic drug combination. The mechanisms of Ya-hom inhibition of histamine action in vivo as compared to histamine stimulation of parietal cells in vitro requires further investigation to elucidate the various pathways that may be affected by Ya-hom exposure.

\section{ACKNOWLEDGEMENT}

This research is supported by NIH grant DK31900) and Faculty of Pharmacy, Mahidol University.

\section{Conflict of interest}

The authors declare that they have no conflict of interest.

\section{Funding}

None to declare.

\section{Ethics approval}

All animal procedures were reviewed and approved by the Animal Care and Use Committee at the Medical College of Georgia, protocol no. 05-08-167.

\section{Article info:}

Received March 3, 2021

Received in revised form May 25, 2021

Accepted May 25, 2021

\section{REFERENCES}

1. Hakanson R, Liedberg G, Oscarson J, Rehfeld JF, Stadil F. Effect of deglycyrrhizinized liquorice on gastric acid secretion, histidine decarboxylase activity and serum gastrin level in the rat. Experientia. 1973;29(5):570-1.

2. Londonkar RL, Poddar PV. Studies on activity of various extracts of Mentha arvensis Linn against drug induced gastric ulcer in mammals. World J Gastrointest Oncol. 2009;1(1):82-8.

3. Mukherjee M, Bhaskaran N, Srinath R, Shivaprasad HN, Allan JJ, Shekhar D, et al. Anti-ulcer and antioxidant activity of GutGard. Indian J Exp Biol. 2010;48(3):269-74.

4. Yashikawa M, Hatakeyama S, Yamahara J. Extraction of sesquiterpenes (saussureamines) from Saussurea lappa and their antiulcer activities. Jpn Kokai Tokyo Koho JP 06, 211, 826 [94, 211, 836] (C1. C07D307/93), 2 Aug 1994, Appl. 93/6, 947, 19 Jan 1993; 12pp.

5. Tanaka S, Yoon YH, Fufui H, Tabata M, Akira T, Okano K, et al. Antiulcerogenic compounds isolated from Chinese cinnamon. Planta med. 1989;55(3):245-8.

6. Hoser S, Winkelmann V, Baumgartel A, Mishenzon N, AbdelAziz H, Kelber O, et al. Interactions of herbal constituents influences the effects of STW 5 on inflammatory processes and disturbed motility. Planta Med. 2013;79-PN44.

7. Chan SS, Zhao M, Lao L, Fong HH, Che C. Magnolol and honokiol account for the anti-spasmodic effect of Magnolia officinalis in isolated guinea pig ileum. Planta Med. 2008;74(4): 381-4.

8. Ashish N, Ashok K, Sumeet G, Varun S, Vishal D, Srinivasan BP. Assessment of spasmolytic activity of alcoholic extract of Achillea millefolium, Rubia cordifolia and Saussurea lappa in Wistar albino rats. Int Res J Pharm. 2013;4(7):64-7.

9. Debelmas AM, Rochat J. Pharmacologic study of essential oils; antispasmodic activity of fifty samples. Plant Med Phytother (Fr). 1967;1(1):23-7.

10. Reiter M, Brandt W. Relaxation effects on tracheal and ileal smooth muscles of the guinea pig. Arzneimittelforschung. 1985; 35(1A):408-14.

11. Liu GQ, Sun JH, He ZZ, Jiang Y. Spasmolytic effects of active principles of essential oil of Acorus gramineus. Acta Pharmacol Sin. 1983;4:95-7.

12. Suvitayavat W, Kodjawongs J, Thirawarapan SS, Bunyapraphatsara N. Effect of Ya-hom on gastric secretion in rats. J Ethnopharmaco. 2004;94(2-3):331-8.

13. Chantharungsikul D, Thirawarapan SS, Bunyapraphatsara N, Suvitayavat W. Inhibition of gastric acid secretion by Ya-hom in isolated mouse whole stomach. Asian Biomed. 2009;3(6):663-73.

14. Song J, Zhang J, Xu j, Garcia-Barrio M, Chen YE, Yang D. Genome engineering technologies in rabbits. J Biomed Res. 2021;35(2):135-47.

15. Mulvihill SJ, Pappas TN, Debas HT. Characterization of in vivo acid secretory responses of rabbit with comparison to dog and rat. Dig Dis Sci. 1989;34(6):895-904.

16. Berglindh T, Obrink KJ. A method for preparing isolated glands from the rabbit gastric mucosa. Acta Physiol Scand. 1976;92(2): 150-9.

17. Berglindh T. Effects of common inhibitors of gastric acid secretion of secretagogue-induced respiration and aminopyrine accumulation in isolated gastric glands. Biochim Biophys Acta. 1977;464(1):217-33.

18. Chew CS, Hersey SJ, Sachs G, Berglindh T. Histamine responsiveness of isolated gastric glands. Am J Physiol. 1980;238: G312-20.

19. Chew CS. cAMP Technologies, functional correlates in gastric parietal cells. Methods Enzymol. 1990;191:640-61.

20. Berglindh T. Gastric glands and cells: preparation and in vitro methods. Methods Enzymol. 1990;192:93-107.

21. Chew CS, Brown MR. Release if intracellular $\mathrm{Ca} 2+$ and elevation of inositol trisphosphate by secretagogues in parietal and chief cells isolated from rabbit gastric mucosa. Biochim Biophys Acta. 1986;888(1):116-25.

22. Chew CS, Ljungstrom M, Smolka A, Brown MR. Primary culture of secretagogue-responsive parietal cells from rabbit gastric mucosa. Am J Physiol. 1989;256(1 Pt 1):G254-63.

23. Ljungstrom, Chew CS. Calcium oscillations and morphological transformations in single cultured gastric parietal cells. Am J Physiol. 1991;260(1 Pt 1):C67-78.

24. Chew CS, Nakamura K, Ljungstrom M. Calcium signaling mechanisms in the gastric parietal cell. Yale J Biol Med. 1992; 65(6):561-76.

25. Chew CS, Parente JA Jr, Zhou C, Baranco E, Chen X. Lasp-1 in a regulated phosphoprotein within the cAMP signaling pathway in the gastric parietal cell. Am J Physiol. 1998;275:C56-67.

26. Chew CS, Chen X, Parente JA Jr, Tarrer S, Okamoto C, Qin H. Lasp-1 binds to non-muscle F-actin in vitro and is localized within multiple sites of dynamic actin assembly in vivo. J Cell Sci. 2002;115(Pt 24):4787-99.

27. Chew CS, Nakamura K, Petropolous AC. Multiple actions of epidermal growth factor and TGF $\alpha$ on rabbit gastric parietal cell function. Am J Physiol. 1994;267(5 Pt 1):G818-26.

28. Chew CS, Parente JA Jr, Chen X, Chaponnier C, Cameron RS The LIM and $\mathrm{SH}_{3}$ domain-containing protein, Lasp-1, may link 
the cAMP signaling pathway with dynamic membrane restructuring activities in ion transporting epithelia. J Cell Sci. 2000; 113(Pt 11):2035-45.

29. Ambler SK, Poenie M, Tsien RY, Taylor P. Agonist-stimulated oscillations and cycling of intracellular free calcium in individual cultured muscle cells. J Biol Chem. 1988;263(4):1952-9.

30. Chew CS, Chen X, Bollag RJ, Isales C, Ding KH, Zhang H. Targeted disruption of the Lasp-1 gene is linked to increases in histamine-stimulated gastric $\mathrm{HCl}$ secretion. Am J Physiol Gastrointest Liver Physiol. 2008;295:G37-44.

31. Chew CS. Differential effects of extracellular calcium removal and non-specific effects of $\mathrm{Ca} 2+$ antagonists on acid secretory activity in isolated gastric glands. Biochim Biophys Acta. 1985; 846(3):370-8.

32. Forte JG, Yao X. The membrane-recruitment-and-recycling hypothesis of gastric $\mathrm{HCl}$ secretion. Trends Cell Biol. 1996;6(2): 45-8.

33. Chew CS, Petropoulos AC. Thapsigargin potentiated histaminestimulated $\mathrm{HCl}$ secretion in gastric parietal cells but not mimic cholinergic response. Cell Regul. 1991;2:27-39.

34. Liu B, Yang J, Wen Q, Li Y. Isoliquiritigenin, a flavonoid from licorice, relaxes guinea-pig tracheal smooth muscle in vitro and in vivo: role of cGMP/PKG pathway. Eur J Pharmacol. 2008; 587(1-3):257-66.

35. Bose BC, Saifi AQ, Vijayvargiya R, Sharma SK. Chemical and pharmacological study of Saussarea lappa. J Pharm Sci. 1961; 50:679-81.

36. Panula P, Chazot PL, Cowart M, Gutzmer R, Leurs R, Liu WLS, et al. International union of basis and clinical pharmacology. XCVIII. Histamine receptors. Pharmacol Rev. 2015;67(3): 601-55.

37. Broadley KJ, Kelly DR. Muscarinic receptor agonists and antagonists. Molecules. 2001;6(3):142-93.

38. Yao X, Forte JG. Cell biology of acid secretion by the parietal cell. Ann Rev Physiol. 2003;65:103-31.

39. Muto Y, Nagao T, Yamada M, Mikoshiba K, Urushdani T. A proposed mechanism for the potentiation of cAMP-mediated acid secretion by carbachol. Am J Physiol Cell Physiol. 2001; 280:C155-65.

40. Chew CS, Zhou CJ, Parente Jr JA. Ca2+-independent protein kinase $\mathrm{C}$ isoforms may modulate parietal cell $\mathrm{HCl}$ secretion. Am J Physiol. 1997;272(2 Pt 1):G246-56. 